\title{
Samuel P. Huntington, Brazilian 'Decompression' and Democracy
}

\author{
Anthony W. Pereira (iD \\ Professor, Brazil Institute and Department of International Development, King's College London \\ Corresponding author. E-mail: anthony.pereira@kcl.ac.uk
}

\begin{abstract}
The Harvard political science professor Samuel P. Huntington (1927-2008) made visits to Brazil in 1972 and 1974 to advise the government about 'decompression' or regime liberalisation. The literature on Brazil's dictatorship references these visits as having had a major causal impact. This article argues that his influence on Brazilian regime change is greatly exaggerated. It also argues that Huntington, who became a leading theorist of democratisation, had an interest in and commitment to democracy that was more recent and circumstantial than is often thought. This helps to explain the current period of democratic 'deconsolidation' associated with the rise of authoritarian national populism in Brazil.
\end{abstract}

Keywords: liberalisation; Samuel P. Huntington; Brazilian dictatorship; democratisation; democracy

\section{Introduction}

The Brazilian dictatorship of 1964-85 was a long-lasting and influential authoritarian regime. One of the key elements of its trajectory was the process of regime liberalisation that began in the mid-1970s. This liberalisation - or 'decompression' as it was sometimes initially called - remains insufficiently understood. As the author of a history of the relationship between the military regime and universities argues, 'A definitive analysis of the origins of decompression has not yet been made, and the theme remains open to new interpretations.'

Some scholars suggest that the Harvard political scientist Samuel P. Huntington (1927-2008), who made two high-level visits to Brasília in 1972 and 1974, exercised a major influence on the regime, helping to shape both the timing and form of liberalisation. Many of these accounts make passing references to Huntington without giving any concrete evidence of his influence. ${ }^{2}$

\footnotetext{
${ }^{1}$ Rodrigo Patto Sá Motta, As universidades e o regime militar (Rio de Janeiro: Jorge Zahar, 2014), p. 325. This and all other translations from Portuguese texts have been made by the author.

${ }^{2}$ See, for example, Ronaldo Costa Couto, História indiscreta da ditadura e da abertura: Brasil: 1964-1985 (Rio de Janeiro: Editora Record, 1999); Elio Gaspari, A ditadura derrotada (Rio de Janeiro: Editora Intrinseca, 2014); Rejane Carolina Hoeveler, 'Samuel Huntington e a transição gradualista no Brasil (1972-1974)' (Paper presented at the International Colloquium 'The Collapse of Dictatorships: Southern Europe, Latin America, Eastern Europe, and South Africa - History and Memory', Federal University of

(C) The Author(s), 2021. This is an Open Access article, distributed under the terms of the Creative Commons Attribution licence (http://creativecommons.org/licenses/by/4.0/), which permits unrestricted re-use, distribution, and reproduction in any medium, provided the original work is properly cited.
} 
This article focuses on Huntington's advice to the government of Brazil during the military dictatorship. It is not an attempt to analyse the broader and complex political history of the Brazilian military regime, of which there is a rich literature. ${ }^{3}$ Its main argument is that Huntington's impact on the regime's liberalisation has been greatly exaggerated.

It is important to add that the approach taken here is to define influence as problem solving, and to measure it in practical terms, by comparing what was recommended to the regime and what was done. This is how the issue is generally dealt with in the literature on Brazil's decompression, and there is also a long tradition in political science, from Machiavelli to the present day, of academics trying to persuade rulers to implement their preferred policies.

The article comprises three sections. The first section describes who Huntington was and why he was invited to advise the Brazilian government. This section suggests that the conventional explanation for liberalisation should be revised or at least complemented by a focus on the dynamics of the Emílio Médici government (1969-74) before the presidency of Ernesto Geisel (1974-9). The second section examines the advice Huntington gave to the Geisel government and what the Geisel and João Figueiredo (1979-85) governments chose to do with his suggestions. This section argues that these governments ignored Huntington's most important recommendations as they pursued liberalisation. The third section focuses on Huntington's ambivalence about democracy in Brazil and elsewhere and argues that the evolution of Huntington's thinking sheds light on some of the weaknesses of the democracies created in the so-called 'third wave' of democratisation (1974-91), as well as on those of older democracies.

\section{Huntington and his Invitation to Advise the Brazilian Government}

Huntington was amongst the best-known scholars of his generation, described by his Harvard colleague Henry Rosovsky, an economist, as 'one of the most influential political scientists of the last 50 years'. ${ }^{4}$ Huntington is unusual in having written landmark books in three different subfields of political science: US politics (The

Rio de Janeiro, 24-6 Oct. 2012); Renato Luís do Couto Neto e Lemos, 'A conexão Harvard e a política de descompressão: sobre as origens da transição política no Brasil pós-64', Tempos Históricos, 18 (2014), pp. 559-90; Robert Putnam, 'Samuel P. Huntington: An Appreciation', PS, 19: 4 (1986), pp. 837-45; Kenneth P. Serbin, Secret Dialogues: Church-State Relations, Torture, and Social Justice in Authoritarian Brazil (Pittsburgh, PA: University of Pittsburgh Press, 2000); and Thomas E. Skidmore, The Politics of Military Rule in Brazil, 1964-85 (Oxford: Oxford University Press, 1988).

${ }^{3}$ See, for example, Leslie Bethell and Celso Castro, 'Politics in Brazil under Military Rule, 1964-1985', in Leslie Bethell (ed.), The Cambridge History of Latin America, vol. 9: Brazil since 1930 (Cambridge: Cambridge University Press, 2008), pp. 165-230; Costa Couto, História indiscreta; Ronaldo Costa Couto, Memória viva do regime militar: Brasil, 1964-1985 (Rio de Janeiro: Editora Record, 1999); Maria D’Araújo and Celso Castro (eds.), Ernesto Geisel (Rio de Janeiro: Editora FGV, 1997); Carlos Fico, Além do golpe: versóes e controvérsias sobre 1964 e a ditadura militar (Rio de Janeiro: Editora Record, 2004); Marcos Napolitano, 1964: História do Regime Militar Brasileiro (São Paulo: Editora Contexto, 2014); and Skidmore, The Politics of Military Rule in Brazil.

${ }^{4}$ Quoted in Corydon Ireland, 'Samuel Huntington, 81, Political Scientist, Scholar', The Harvard Gazette, 5 Feb. 2009. See also Jane S. Jaquette and Abraham F. Lowenthal, 'Samuel P. Huntington (1927-2008)', Estudios Internacionales, 162 (2009), pp. 107-24. 
Soldier and the State, American Politics: The Promise of Disharmony, Who are We?), comparative politics (Political Order in Changing Societies and The Third Wave) and international relations (The Clash of Civilizations). ${ }^{5}$ Huntington was not a Latin Americanist or Brazilianist. ${ }^{6}$

Huntington was both an academic and a policy advisor. As an academic at Harvard, he served as Chair of the Government Department from 1967 to 1969 and from 1970 to 1971, and as Director of the Center for International Affairs from 1978 to 1989. In 1989 he founded the Olin Institute of Strategic Studies at Harvard, and served as its Director until 1999. He was also President of the American Political Science Association in 1986-7. In the policy realm, he advised the US government on the Vietnam War from 1966 to 1969 (chairing the Vietnam subcommittee of the Southeast Asia Development Advisory Group), served as a foreign policy advisor to presidential candidate (and then Vice-President) Hubert Humphrey in 1968, co-founded the journal Foreign Policy in 1971, and served on the National Security Council (as Coordinator of Security Planning) from 1977 to 1978 under President Jimmy Carter. ${ }^{7}$

Huntington was something of a prodigy, and had a career that would be virtually impossible today. He was born in New York City in 1927, to a family that traced its lineage back to immigrants to New England in 1633. His mother was a writer, his father an editor, and one of his grandfathers was a publisher and leading progressive reformer. ${ }^{8}$ He went to the Peter Stuyvesant High School on East 15th Street, an exam-based state school, where he completed his studies at age 16, two years ahead of his peers. He attended Yale College and finished his undergraduate degree in 1946 in only two and a half years, majoring in international relations. He served in the Army in 1947-8, started a master's degree at the University of Chicago, transferred to Harvard in 1948, and defended his $\mathrm{PhD}$ thesis on US politics in 1951, becoming an assistant professor in the Government Department at Harvard at the age of 23. He stayed at Harvard for the rest of his career, except

\footnotetext{
${ }^{5}$ The Soldier and the State: The Theory and Politics of Civil-Military Relations (Cambridge, MA: Harvard University Press, 1957); American Politics: The Promise of Disharmony (Cambridge, MA: Harvard University Press, 1981); Who are We? The Challenges to America's National Identity (New York: Simon and Schuster, 2004); Political Order in Changing Societies (New Haven, CT: Yale University Press, 1968); The Third Wave: Democratization in the Late Twentieth Century (Norman, OK: University of Oklahoma Press, 1991); and The Clash of Civilizations and the Remaking of World Order (London: The Free Press, 1996). The latter was translated into Portuguese and published as $O$ choque de civilizações by Objetiva, a São Paulo publisher, in 1997.

${ }^{6}$ Research conducted by this author in Aug.-Sept. 2015 in Huntington's personal papers uncovered very few texts in Portuguese or Spanish, despite the numerous files containing press clippings and academic papers. Huntington's personal papers can be consulted in the Phillips Reading Room at the Pusey Library at Harvard University: Harvard University Archives, Samuel P. Huntington Personal Archive, 1905-2008, HUM 178 (hereafter Huntington Archive). One of Huntington's former students, Jorge Domínguez, wrote: 'Huntington has never claimed to be an expert on Latin America; indeed, he has never presented himself as an expert on any of the world's geographic regions': Jorge I. Domínguez, 'Samuel Huntington and the Latin American State', in Miguel Angel Centeno and Fernando López-Alves (eds.), The Other Mirror: Grand Theory through the Lens of Latin America (Princeton, NJ: Princeton University Press, 2001), pp. 219-39; here p. 231.

${ }^{7}$ Putnam, 'Samuel P. Huntington'.

${ }^{8}$ Ibid., p. 837. John Sanborn Phillips was co-editor of McClure's.
} 
for a four-year stint at Columbia from 1958 to $1962 .{ }^{9}$ He retired from teaching in 2007, and died in 2008.

At the time of his visits to Brazil in the early 1970s, Huntington was at the heart of the US academic and foreign policy establishment, with a home on Beacon Hill in Boston, a summer residence on Martha's Vineyard and, as his personal papers show, close contact with a wide range of academics and government officials, including Zbigniew Brzezinski (later head of the National Security Council under President Jimmy Carter), Henry Kissinger, Secretary of State under Presidents Richard Nixon and Gerald Ford, Lincoln Gordon, US ambassador to Brazil from 1961 to 1966, George Kennan, a diplomat and theorist of the 'containment' of Communism during the Cold War, and many others.

Several aspects of Huntington's thought reveal affinities with the ideas of the leaders of Brazil's military regime, and help to explain how he eventually advised the regime in the early 1970s. Although he was a Democrat, and worked for the Adlai Stevenson campaign as a speechwriter in 1956, Huntington was a self-described conservative. In a 1957 article in The American Political Science Review, then, as now, the flagship journal for US political science, Huntington revealed his admiration for conservatism, the 'passionate affirmation of the value of existing institutions'. ${ }^{10}$ His was a Burkean conservatism that saw people as religious animals; society as a natural, organic product of slow historical growth; human beings as instinctual and emotional, not just rational actors; community as superior to the individual; human beings as inherently unequal; and was sceptical of visions of reform and change - 'Efforts to remedy existing evils usually result in even greater ones. ${ }^{11}$ Huntington was also Burkean in his respect for the preservation of institutions regardless of their substance - he admired Edmund Burke for defending 'Whig institutions in England, democratic institutions in America, autocratic institutions in France, and Hindu institutions in India', or in other words 'all existing institutions wherever located and however challenged.' ${ }^{12}$

Huntington's conservatism was linked to his anti-Communism. At the end of his article 'Conservatism as an Ideology' he wrote, with regard to the United States,

the greatest need is not so much the creation of more liberal institutions as the successful defense of those which already exist. This defense requires American liberals to lay aside their liberal ideology and to accept the values of conservatism for the duration of the threat [of Soviet communism]. Only by surrendering their liberal ideas for the present can liberals successfully defend their liberal institutions for the future ... Until the challenge of communism and the Soviet Union is eliminated or neutralized, a major aim of

\footnotetext{
${ }^{9} I b i d .$, pp. 837-40. See also 'In Memoriam: Samuel P. Huntington', at http://wcfia.harvard.edu/publications/memoriam-samuel-p-huntington, last accessed 12 Feb. 2021.

${ }^{10}$ Samuel P. Huntington, 'Conservatism as an Ideology', The American Political Science Review, 51: 2 (June 1957), pp. 454-73; here p. 455.

${ }^{11}$ Ibid., p. 456.

${ }^{12} \mathrm{Ibid}$., p. 463. Huntington seems never to have lost his conservatism. In an email to Brzezinski dated 31 Aug. 2005, he thanked his friend for associating him in an essay with Oswald Spengler and Arnold Toynbee, 'both of whom I admire although not many people do these days': Huntington Archive, Box 28, Folder 13.
} 
American liberals must be to preserve what they have created. This is a limited goal but a necessary one ... In preserving the achievements of American liberalism, American liberals have no recourse but to turn to conservatism. ${ }^{13}$

This idea resonates with the ideology of Brazil's military dictatorship, which restricted democratic rights in order, it claimed, to save democracy and to prevent the spread of Communism. Huntington's remark 'To continue to expound the philosophy of liberalism simply gives the enemy a weapon with which to attack the society of liberalism' would have been met with approval by the defenders of Brazil's authoritarian regime. ${ }^{14}$

Huntington was also an analyst of civil-military relations in the United States. His first book, The Soldier and the State, is still influential in its analysis of different pathways to civilian control over the military. It is also a normative defence of the military way of life and of military values. Huntington saw the military in the United States of that time (the book was published in 1957) as a uniquely important institution because it served as the guardian of the nation that he cherished. The book ends with a lyrical passage called 'The Worth of the Military Ideal' about the virtues of military order in comparison to the chaos and squalor of civilian life:

West Point [the US Military Academy] embodies the military ideal at its best; Highland Falls [the town outside the academy] the American spirit at its most commonplace. West Point is a gray island in a many colored sea, a bit of Sparta in the midst of Babylon. Yet is it possible to deny that the military values - loyalty, duty, restraint, dedication - are the ones America needs today? ... If the civilians permit the soldiers to adhere to the military standard, the nations themselves may eventually find redemption and security in making that standard their own. ${ }^{15}$

In the late 1950s Huntington turned away from the study of the United States, in part because he viewed his prospects at Harvard in that subfield as limited, due to the presence of a prominent specialist in US politics, V. O. Key. ${ }^{16} \mathrm{He}$ entered the sphere of comparative politics and began to study so-called 'developing' countries. In the autumn of 1964 he founded, with Myron Weiner of the Massachusetts Institute of Technology (MIT), the Boston-area Joint Seminar on Political Development (JOSPOD). ${ }^{17}$ JOSPOD united a group of scholars who used the framework of modernisation theory, then the dominant paradigm in comparative politics in the United States, to analyse 'developing' societies in Asia, Africa and Latin America. In modernisation theory, the 'political development' of 'developing' societies could be generalised about using empirical analysis and models.

\footnotetext{
${ }^{13}$ Huntington, 'Conservatism as an Ideology', pp. 472-3.

${ }^{14}$ Ibid., p. 473.

${ }^{15}$ Huntington, The Soldier and the State, p. 466. Huntington was denied tenure at Harvard in 1958, and one of the reasons was that critics saw in The Soldier and the State an authoritarian admiration for militarism. After four years at Columbia, Huntington was invited back to Harvard to a tenured professorship: Putnam, 'Samuel P. Huntington', p. 840.

${ }^{16}$ Ibid., p. 839, footnote 8 .

${ }^{17}$ Ibid., p. 841.
} 
In his Political Order in Changing Societies (1968), Huntington registered his dissent from one of the key assumptions of modernisation theory, the idea that economic development and democracy went hand in hand. In the memorable opening section of the book, he wrote: 'The most important political distinction among countries concerns not their form of government but their degree of government. The differences between democracy and dictatorship are less than the differences between those countries whose politics embodies consensus, community, legitimacy, organization, effectiveness, stability, and those countries whose politics is deficient in those qualities. ${ }^{18}$ The book reflects on the breakdown of democracy in many newly-independent states of Asia and Africa, as well as Latin America.

In a section of Political Order in Changing Societies, Huntington analyses the dilemmas of armed forces that came to power in the developing world as the result of a 'veto coup', a military coup d'état to prevent a popularly elected leader from engaging in a process of political mobilisation and reform. Huntington identified the 1964 coup in Brazil as just such an intervention, and outlined four strategies for military leaders who ruled after such a coup. One of them was the 'Castelo Branco option', named after Brazil's first military president after the coup, which Huntington describes as a dilemma in which the leaders, 'whatever intentions they may have had to the contrary ... are inevitably driven to more and more repressive measures. ${ }^{19}$ In this passage, Huntington identified a problem that Brazil's military leaders themselves recognised in the early 1970s.

Huntington became interested in Brazil in the early and mid-1960s, as the extensive references to Brazil in Political Order show. (The index contains 29 references to Brazil, more than for Argentina - 21 - and Chile - 18 - but fewer than those to Mexico and the Mexican Revolution - 51. ${ }^{20}$ His first trip to Brazil was in October of 1965, when he was invited to a conference by Cândido Mendes. ${ }^{21}$ Mendes - an intellectual, scholar, social critic, editor, president of the university founded by his grandfather, and entrepreneur, and a major force in the development of the social sciences in Brazil - was a thinker who placed himself within the Christian Democratic centre in Brazil and had helped to found the History Department in the Instituto Superior de Estudos Brasileiros (Higher Institute for Brazilian Studies, ISEB), a leading national-developmentalist think tank in Rio created under the auspices of the Ministry of Education. ${ }^{22}$ Mendes had first met Huntington when he spent time as a visitor at Harvard University, a position he obtained with the help of the US ambassador to Brazil Gordon. ${ }^{23}$ He also played a role as a mediator between the dictatorship and its opposition, in which he tried to protect academic freedom and promote political liberalisation.

\footnotetext{
${ }^{18}$ Huntington, Political Order in Changing Societies, p. 1. The distinction between the form and degree of government was first made by Huntington in 'Political Order and Political Decay', World Politics, 17: 3 (April 1965), pp. 386-430.

${ }^{19}$ Huntington, Political Order in Changing Societies, p. 235.

${ }^{20}$ Ibid., pp. $464-75$.

${ }^{21}$ Author interview with Mendes, Rio de Janeiro, 12 April 2017.

${ }^{22}$ Alzira Alves de Abreu, Israel Beloch, Fernando Lattman-Weltman and Sérgio Tadeu de Niemeyer Lamarão (eds.), Dicionário histórico-biográfico brasileiro pós-1930, vol. 4 (Rio de Janeiro: Editora FGV, 2001), p. 3751.

${ }^{23}$ Author interview. Mendes spent a total of five years in the United States in the 1960s as an academic visitor at Harvard, Columbia and the University of California - Los Angeles (UCLA).
} 
In many ways Mendes and Huntington were similar. They shared elite social backgrounds and religious orientations (although Huntington was an Episcopalian rather than, as was Mendes, a Catholic). They both thought that Brazil's military regime could develop the country by combining nationalism with technocratic administration. ${ }^{24}$ But in many ways they were also different. Mendes was a Catholic activist and someone who defended political prisoners in the name of social justice. ${ }^{25}$ He published a book in 1966 in which he portrayed the Catholic Left as a force for progressive social change in Brazil. ${ }^{26}$ For these reasons he was regarded sceptically by some military regime leaders as a Church activist who meddled in political affairs. Huntington's instincts were more conservative and hierarchical. ${ }^{27}$

As a prominent academic at the Center for International Affairs at Harvard, Huntington was able to learn about Brazil from a number of visiting Brazilian academics, including the political scientist Hélio Jaguaribe, the law professor Celso Lafer, the economist Edmar Bacha and Mendes. ${ }^{28}$ Huntington went back to Brazil in September 1966 for a seminar on political development at the Federal University of Minas Gerais (UFMG) in Belo Horizonte, organised jointly by Harvard's Center for International Affairs and UFMG. (The Ford Foundation gave money to develop political science at UFMG and to fund UFMG professors to do PhDs at Harvard, Stanford, Michigan and other US universities.) $)^{29}$ Attending the seminar were current and future luminaries of comparative political science: Brazilians Gláucio Ary Dillon Soares, Fábio Wanderley Reis, Mendes and Octavio Ianni, and non-Brazilians Dankwart Rustow, David Apter, Harry Eckstein, Samuel Eisenstadt, Lucian Pye, Leonard Binder, David McClelland, Giovanni Sartori, Torcuato di Tella and Pablo González Casanova. Huntington's third trip to Brazil occurred in 1968 when, again at Mendes' invitation, he participated in a seminar in Rio on the study of politics and legislation. ${ }^{30}$

An incident that occurred during the Belo Horizonte conference (13-18 September 1966) showed the power of Huntington's connections with the US foreign policy establishment. Bolívar Lamounier, then a young research assistant to Mendes in Rio, had received a student visa from the US embassy on 13

\footnotetext{
${ }^{24}$ Serbin, Secret Dialogues, p. 246.

${ }^{25}$ Mendes' brother Luciano, a priest, was President of the Conferência Nacional dos Bispos do Brasil (National Confederation of Brazilian Bishops, CNBB) from 1987 to 1995.

${ }^{26}$ Cândido Mendes, Memento dos vivos: a esquerda católica no Brasil (Rio de Janeiro: Tempo Brasileiro, 1966).

${ }^{27}$ An example of Huntington's conservative instincts can be seen in his reaction to the Watergate crisis in the United States in 1974. In an exchange of letters with Anthony Lewis, then a columnist with The New York Times, he complained that President Nixon had been unfairly forced out for personal reasons, had done nothing that other presidents had not done, and that Nixon's resignation was not an advance for democracy, as Lewis argued. Huntington Archive, Box, 1, Folder 48, 'Lewis, Anthony 1971, 1975'.

${ }^{28}$ Huntington Archive, Box 71, Folder 35, 'Notes on a Panel at the Center for International Affairs in 1973, with Comments on the Brazilian Situation by Mendes, Bacha, Lafer and Jaguaribe'.

${ }^{29}$ For more on the role of the Ford Foundation in promoting a new approach to the social sciences in Brazil, see Jeremy Adelman and Margarita Fajardo, 'Between Capitalism and Democracy: A Study in the Political Economy of Ideas in Latin America, 1968-1980', Latin American Research Review, 51: 3 (2016), pp. 3-22, especially p. 8.

${ }^{30}$ Lemos, 'A conexão Harvard', pp. 561-6.
} 
September 1966 which was revoked on 14 September when embassy staff received information that Lamounier had been charged in a military court with membership of the Communist Party, a violation of the national security laws of the time. (He denied the charge.) Lamounier was arrested by the political police (DOPS; Departamento de Ordem Política e Social) on the steps of the US consulate in Belo Horizonte during the conference as he left following an attempt to find out why his visa had been revoked. The circumstances of the arrest gave the impression that the US consulate had called the DOPS while Lamounier was inside the building. Lamounier spent time in prison before being released.

Huntington interceded on Lamounier's behalf. He wrote a letter to Gordon, former US ambassador to Brazil and at the time Assistant Secretary of State for Inter-American Affairs at the Department of State. Huntington had first met Gordon when the latter was a professor at Harvard Business School in the 1950s. The letter, dated 4 October 1966, included this passage:

The Ford Foundation program in Minas Gerais is designed to promote a systematic empirical approach to social science and to social problems in place of the ideological approach which has been so dominant in Latin America. Whatever his earlier ideological tendencies, Lamounier has given every indication of welcoming the empirical approach and of becoming a pragmatic social scientist of precisely the type which Brazil needs and which it is in the US national interest to encourage. If, however, the actions of Price [the US consul general in Belo Horizonte] are duplicated elsewhere and if the Lamouniers of Latin America are denied visas and put in military prisons on specious grounds and with fragmentary evidence, we will leave those Lamouniers little alternative but to become what we falsely accuse them of already being. ${ }^{31}$

Eventually, Lamounier received his visa and went to do a master's degree in political science at the University of California - Los Angeles (UCLA). Huntington noted this in another letter to Gordon dated 19 January 1967, in which he thanked Gordon, praised Frank Carlucci and Donald Wallace, officials in the US embassy in Rio, for helping facilitate the visa, and celebrated the fact that Lamounier had become a 'constructive scholar' who was no longer 'hostile to the United States.' ${ }^{32}$

Huntington's link to the Brazilian dictatorship began with his friendship with the Brazilian academic Mendes. Through Mendes, Huntington was invited to serve as a consultant by the government of President Médici in $1972 .{ }^{33}$ Brazil's

\footnotetext{
${ }^{31}$ Huntington Archive, Box 1, Folder 30, 'Letter to Lincoln Gordon', p. 3. Huntington's advising of PhD students reflected his commitment to an empirical approach to political science. For example, his student Fábio Wanderley Reis wanted to write a purely theoretical thesis, but Huntington pushed him to include empirical material: Huntington Archive, Box 2, Folder 7, 'Letter to Fabio Wanderley Reis'.

${ }^{32}$ Huntington Archive, Box 1, Folder 30, 'Letter to Lincoln Gordon'. Carlucci went on to become the US ambassador to Portugal from 1974 to 1978, and was head of the National Security Council (1986-7) and Secretary of Defense (1987-9) in the Reagan administration (1981-9). Following the transfer of the Brazilian capital to Brasília in 1960, the US embassy officially moved there from Rio in 1971.

${ }^{33}$ Serbin writes that Mendes was a friend of José Guilherme Merquior, an intellectual and advisor to Leitão de Abreu, and it was this connection that led to the invitation to Huntington: Secret Dialogues, p. 247.
} 
military dictatorship was in its most repressive phase at this time. In late 1968 the regime had issued the Ato Institucional 5 (Fifth Institutional Act, AI-5) that suspended habeas corpus in national security crimes, allowing opponents to be detained, and tortured, indefinitely. AI-5 endowed the executive branch with extraordinary emergency powers. Congress was closed for most of 1969; it was eventually reopened, but with fairly limited powers. In dealing with a small number of armed Left groups, the regime created a large repressive apparatus and engaged in torture on a broad scale, with some killings and disappearances. ${ }^{34}$ Those accused of crimes against national security were tried in military courts. ${ }^{35}$

In his trip to Brazil, Huntington met with Médici's Chief of Staff (Secretário do Gabinete Civil) José Leitão de Abreu on 13 October 1972. Mendes organised the meeting: he may have felt that because he was viewed with suspicion in Brasília, he could encourage liberalisation more effectively by bringing in an outsider, one untainted by previous involvement in Brazilian politics. Leitão de Abreu was interested in talking to Huntington about the possibilities of distensão or decompression (also sometimes referred to as descompressão in Brazil). Huntington also spoke to the Minister of Finance Antônio Delfim Netto on this trip.

Huntington claimed that both Leitão de Abreu and Delfim Netto 'recognized the need for an end to the extreme forms of repression that had existed and for an opening of the political system'. ${ }^{36}$ In Leitão's case, personal ambition was a factor: he hoped to succeed Médici as president. He thought that if he could make the case for some sort of regime relaxation or 'normalisation', he would be endorsed as a civilian candidate in the next indirect election in Congress. He asked Huntington: 'How can decompression occur in authoritarian political systems?' and 'What is the best model for Brazil to follow in this regard? ${ }^{37}$ Leitão asked Huntington to write a paper in response to these questions.

This paper was 'Approaches to Political Decompression'. While never published, it circulated among Brazilian government officials in 1973. It is now available at the archive of the Centro de Pesquisa e Documentação de História Contemporânea do Brasil (Centre for Research and Documentation of Contemporary Brazil, CPDOC) at the Getúlio Vargas Foundation in Rio de Janeiro, as well as in the Huntington Archive. ${ }^{38}$ Huntington was invited back to Brazil in 1974, after the inauguration of President Geisel, and met with Geisel's Chief of Staff, General Golbery do Couto e Silva ('Golbery'), on 8 February 1974.

In summary, Huntington's intellectual predilections and involvement with Brazil made him someone particularly interested in and suited for the job of advising Brazil's generals. He was a conservative and staunch anti-Communist who believed that liberal values had to be subordinated to the defence of political order for the duration of the Cold War, and he was an admirer of the military way of life and values who saw the armed forces as a uniquely important instrument of

\footnotetext{
${ }^{34}$ For an official accounting of the human rights abuses of the Brazilian dictatorship, see Comissão Nacional da Verdade, Relatório, three volumes, 2014, at: http://www.cnv.gov.br/index.php?option=com_content\&view=article\&id=571, last accessed 12 Feb. 2021.

${ }^{35}$ Napolitano, 1964, pp. 79 and 345.

${ }^{36}$ Skidmore, The Politics of Military Rule in Brazil, p. 165.

${ }^{37}$ Ibid., p. 165.

${ }^{38}$ Huntington Archive, Box 71, Folder 34, 'Approaches to Political Decompression'.
} 
order. In liberal democracies, the armed forces could protect democracy; in authoritarian regimes they could protect a non-democratic version of order. In addition, in Political Order in Changing Societies, his most important published work at that time, Huntington had analysed, from the point of view of military officers, the dilemmas of coup makers who intervened in politics to protect establishment interests and exclude the advocates of radical change from politics. His contact with Mendes gave him access to the highest levels of the Brazilian government. ${ }^{39}$

Furthermore, the invitation to Huntington from José Leitão de Abreu shows that liberalisation was not simply, as it is sometimes portrayed in the literature, a personal project of Geisel and Golbery. ${ }^{40}$ The perceived need for liberalisation was a concern of several leading figures in the last phase of the Médici administration.

\section{Huntington's Advice on Decompression and the Government's Actions}

Huntington's high-level visits to Brazil in 1972 and 1974 have generally been interpreted by both Brazilian and non-Brazilian scholars as exemplifying the important role that he played in the liberalisation of Brazil's authoritarian regime. In particular, he is often given credit for influencing the conservative and top-down ('lenta, gradual, e segura' or 'slow, gradual and secure') approach to liberalisation taken by the regime's leaders. To understand this process, it is important to distinguish between liberalisation and democratisation. The former has been defined as 'the process of making effective certain rights that protect both individuals and social groups from arbitrary or illegal acts committed by the state or third parties'. ${ }^{41}$ Democratisation has been defined as

the processes whereby the rules and procedures of citizenship are either applied to political institutions previously governed by other principles (e.g., coercive control, social tradition, expert judgment, or administrative practice), or expanded to include persons not previously enjoying such rights and obligations (e.g. nontaxpayers, illiterates, women, youth, ethnic minorities, foreign residents), or extended to cover issues and institutions not previously subject to citizen participation (e.g., state agencies, military establishments, partisan organizations, interest associations, productive enterprises, educational institutions, etc.). ${ }^{42}$

In many transitions to democracy, including the Brazilian, liberalisation preceded democratisation or, 'crucial individual and collective rights were made effective before the convocation of competitive elections, the organization of effective interest representation, and the submission of executive authority to popular accountability.' ${ }^{43}$

The conventional wisdom is that Huntington's 1973 paper 'Approaches to Political Decompression' contained important practical advice for the leaders of Brazil's dictatorship, advice that was taken seriously and followed, and which

\footnotetext{
${ }^{39}$ Mendes emphasised to me his good relations with Golbery, saying that he had known him before the coup of 1964: author interview.

${ }^{40}$ See, for example, Skidmore, The Politics of Military Rule in Brazil.

${ }^{41}$ Guillermo O'Donnell and Philippe C. Schmitter, Transitions from Authoritarian Rule: Tentative Conclusions about Uncertain Democracies (Baltimore, MD: Johns Hopkins University Press, 1986), p. 7.

${ }^{42}$ Ibid., p. 8.

${ }^{43}$ Ibid., p. 10.
} 
profoundly shaped the management of Brazil's regime transition. For Thomas Skidmore, for example, Huntington's talks with Leitão de Abreu and Delfim Netto were 'extensive' in 1972 and Huntington's paper 'stimulated immediate debate among Brazilian intellectuals and academics'. ${ }^{44}$ For Kenneth Serbin, Huntington's conversations with Leitão de Abreu and Delfim Netto in 1972 'stirred debate about decompression in the government and the opposition'. ${ }^{45}$ Elio Gaspari sees Huntington as Kissinger's informal emissary and his visit as an important moment in communication between the Geisel and Nixon administrations. ${ }^{46}$ Ronaldo Costa Couto, for his part, sees Huntington's key role as warning the Geisel administration not to let decompression escape the regime's control. ${ }^{47}$

Critics of Huntington tend to see his influence as even more important than do Skidmore, Serbin, Gaspari and Costa Couto. Rejane Hoeveler, for example, cites the economist Paulo Nogueira Batista as saying that 'the Geisel administration eventually validated some of Huntington's ideas'. ${ }^{48}$ She adds, 'The fact is that the Brazilian "distensionist" project received the strategic collaboration of an important ... intellectual $\ldots$ and this should not be underestimated in the analysis of the [...] project. ${ }^{39}$ In a similar vein, Renato Lemos states, 'he [Huntington] came to Brazil as a strategic element of the policy of the USA in Latin America'. ${ }^{50}$ Lemos goes on to write, 'The prescription made by Samuel Huntington would be rigorously followed by the Geisel and Figueiredo governments ${ }^{51}$ and 'From the inauguration of Ernesto Geisel, the national political process would follow the general lines laid out by the two political scientists [Huntington and Wanderley Guilherme dos Santos]. ${ }^{52}$ Lemos also insists that Huntington 'participated in the elaboration of the regime's transition policies studied by the Médici government. And this participation was translated into practical policies, as the subsequent political process indicates. ${ }^{53}$

Huntington's colleagues, and Huntington himself, encouraged the idea that his visits had a major impact. Robert Putnam, a Harvard colleague, wrote, 'For more than a decade he [Huntington] served as an influential advisor to the Brazilian military government on the problems of gradual liberalisation. ${ }^{, 54}$ Huntington cited the Brazilian example extensively as one of the most successful transitions to democracy, alongside the case of Spain (late 1970s), in his 1991 book The

\footnotetext{
${ }^{44}$ Skidmore, The Politics of Military Rule in Brazil, p. 165.

${ }^{45}$ Serbin, Secret Dialogues, p. 92.

${ }^{46}$ Gaspari, A ditadura derrotada, p. 344 . The idea that Huntington was Kissinger's informal emissary cannot be corroborated, as there is no file for communication between Huntington and Kissinger in Huntington's personal papers. Huntington, Kissinger and Brzezinski overlapped as students and assistant professors of government at Harvard.

${ }^{47}$ Costa Couto, História indiscreta, p. 146.

${ }^{48}$ Hoeveler, 'Samuel Huntington', p. 4, footnote 11.

${ }^{49}$ Ibid., p. 10. In the same passage Hoeveler also describes Huntington as a representative of transnational capital. However, this label conflicts with his denunciation of elites in the United States as insufficiently nationalistic, as well as with his criticism of transnational 'Davos Men', globally connected academics, civil servants and corporate executives, in Who are We?, pp. 264-71 and 272.

${ }^{50}$ Lemos, 'A conexão Harvard', p. 567.

${ }^{51}$ Ibid., p. 580.

${ }^{52}$ Ibid., p. 586.

${ }^{53}$ Ibid., pp. $587-8$.

${ }^{54}$ Putnam, 'Samuel P. Huntington', p. 842.
} 
Third Wave. He nurtured the idea that the Brazilian military regime had retained absolute control over the process of decompression, 'in a sequence precisely defined by the government of exception [de facto government]. ${ }^{55} \mathrm{He}$ described the liberalisation of the Geisel and Figueiredo administrations as 'a two-step forward, one-step backward policy. The result was a creeping democratization in which the control of the government over the process was never seriously challenged.' He praised the transition in Brazil as being so gradual that 'there was no clear break; the genius of the Brazilian transformation is that it is virtually impossible to say at what point Brazil stopped being a dictatorship and became a democracy'. ${ }^{56}$ Huntington also encouraged this reading of Brazilian political history in his personal correspondence. In a letter to his Brazilian friend Mendes written in 2002, he wrote, 'In the meantime, I still have warm memories of our past association and our joint efforts working with General Golbery to help Brazil on the path to democracy. ${ }^{, 57}$

However, Huntington's personal papers suggest that all of these assessments of his influence on the regime's liberalisation are exaggerated. In fact, Huntington's most important recommendations about 'decompression' were ignored by the Geisel administration and its successor, Figueiredo's. The Geisel and Figueiredo administrations, rather than follow Huntington's advice, did the opposite of what he suggested they should do.

The paper that Huntington was commissioned to write by Leitão, 'Approaches to Political Decompression, ${ }^{58}$ is undated but is known to have been read by government officials in Brazil in 1973. Several different drafts can be found in Huntington's personal papers, as well as extensive notes that contributed to the final version. Huntington's meeting on 8 February 1974 with General Golbery in Rio de Janeiro was to discuss the paper. Huntington's visit was noted by the Brazilian press and US diplomats at the time. ${ }^{59}$ A telegram to the Department of State from the US embassy in Brazil dated 19 March 1974 noted that 'Professor Huntington's visit to Rio, during which he met with Geisel intimate General Golbery, added "decompression" to the local political lexicon.' It went on to claim, 'No matter how gradually or carefully carried out, however, decompression seems certain to be a continuing source of difficulty for the Geisel administration. ${ }^{60}$

Huntington's paper is mostly a discussion of the need for and risks of decompression, as well as some principles that should guide the process. Huntington described decompression as having three key elements. First, a definition of the presidential succession process (in order to avoid the conflicts over succession

\footnotetext{
${ }^{55}$ The quote is from the inside back cover of Cândido Mendes, A razão armada (Rio de Janeiro: Garamond, 2012).

${ }^{56}$ Huntington, The Third Wave, p. 126.

${ }^{57}$ Huntington Archive, Box 29, Folder 61, 'Letter to Cândido Mendes', 10 May 2002.

${ }^{58}$ Huntington, 'Approaches to Political Decompression'. It is 16 pages in length.

${ }^{59}$ In Huntington's personal papers there is a clipping of an article that appeared in the Rio newspaper Jornal do Brasil on 10 Feb. 1974, on p. 24 of the first section: 'Especialista dos EUA analisa descompressão' ['Specialist from the USA Analyses Decompression']: Huntington Archive, Box 40, Folder 11, 1970-4. This is one of the few texts in Portuguese found in the archive.

${ }^{60}$ From Sara Berndt, Halbert Jones and James Siekmeier (eds.), Foreign Relations of the United States, 1969-1976, vol. E-11, Part 2, Documents on South America, 1973-1976 (Washington DC: Department of State, 2015), pp. 270-4. The document in question is Item 97, Telegram 1850.
} 
that had occurred in Brazil in 1966 and 1969); second, a broadening of participation within the regime, and third, the restoration of some civil and political rights. The broadening of participation meant the inclusion of powerful interest groups and did not involve mass participation. Huntington made it clear that he did not view decompression as synonymous with civilianisation or democratisation. $\mathrm{He}$ saw decompression as a way to stabilize the authoritarian regime.

Much of Huntington's advice was probably unsurprising to the leaders of the regime. For example, the idea that the process must be gradual, and that the government should retain control over it, avoiding the pitfalls of both a hardline backlash and an oppositional takeover, would have been regarded as common sense by the Geisel administration. The idea that it should not be personalised, or associated exclusively with a single leader, would have seemed sensible. ${ }^{61}$ Similarly, the notion that economic development would have political effects, and these political effects should be studied, was uncontroversial.

Where Huntington innovated was in his recommendations about the system of representation and the sequencing of reform. Huntington advocated for the creation of a dominant-party structure along the lines of the Mexican political system at that time, which was controlled by the Partido Revolucionario Institucional (Institutional Revolutionary Party, PRI): ${ }^{62}$

While clearly there are major differences in the political history and institutions of Brazil and Mexico, a close study of the ways in which the Mexican government has institutionalized the process of presidential succession could well suggest procedures which might be useful in Brazil. ${ }^{63}$

What this suggests is that the time may have come in Brazil for a major political innovation: the creation of a functional political party which is closely tied in with and based on organized socio-economic groups. The government is in a unique position to be able to do this now and to integrate into such a party the broadest range of corporate interests. Such a development could, indeed, be the crucial key to the future political stability of Brazil, because if the government does not do this during the next few years, opposition movements and groups will surely take the initiative away from it.

Huntington carried on in this vein in the paper. 'The party system as a whole might well have certain resemblances to those of Mexico and Japan.

\footnotetext{
${ }^{61}$ Nevertheless, Huntington's advice to have 'decompression without a decompressor' was ignored by Geisel. Geisel was the arbiter of decompression and was personally associated with it, contrary to Huntington's recommendation. For an argument about why so few authoritarian regimes are able to depersonalise political authority, see Milan W. Svolik, The Politics of Authoritarian Rule (Cambridge: Cambridge University Press, 2012), pp. 198-9.

${ }^{62}$ Frances Fukuyama, a former student of Huntington's, dissents from Huntington's views on dominant authoritarian political parties. He writes, 'Huntington believed authoritarian parties could satisfy popular demands for participation, but we see in retrospect that this was not true': Francis Fukuyama, Political Order and Political Decay: From the Industrial Revolution to the Globalization of Democracy (London: Profile Books, 2014), p. 542.

${ }^{63}$ Huntington, 'Approaches to Political Decompression', p. 8.

${ }^{64}$ Ibid., p. 10.
} 
Such a structured system of functionally-based parties would appear to be the most viable alternative to the present system of apolitical authoritarian government-divorced-from-party and a return to the populist, personalistic and weakly-structured party politics which prevailed before $1964 .{ }^{65}$ Of the relevant foreign models discussed in the paper, three were authoritarian dominantparty regimes (Mexico and Turkey in the 1930s and 1940s and Taiwan), and two were totalitarian or Communist single-party regimes (Czechoslovakia before the Soviet invasion in 1967-8, and Yugoslavia from 1964 to 1974). Only one - Japan - was a democracy, in this case a democracy with a dominant party, the Liberal Democratic Party.

Furthermore, Huntington wanted decompression to follow an 'orderly' sequence. First the succession mechanism should be institutionalised. Second, representation and participation should be expanded. And only then should the partial restoration of civil and political rights begin.

One indication that Huntington was not influential comes from those to whom his advice was given. President Geisel, in an interview not long before his death in 1996, said:

There was an attempt [at liberalisation, referred to below as 'normalisation'] in the Médici government, made by Leitão de Abreu. Mr Huntington, an American political scientist, in a visit to Brazil, spoke to Leitão de Abreu about the possibilities of the normalisation of the country without obtaining a practical result. Afterwards, when I was president, he met with Golbery once or twice to talk about the same issue. Once again it did not result in anything. ${ }^{66}$

Golbery, Geisel's advisor, had similar sentiments. He called Huntington's paper on decompression 'pedestrian'. ${ }^{67}$ Golbery thought Huntington was 'weak, but trustworthy'. ${ }^{68}$ Huntington, for his part, described Golbery as the 'Doctor Strangelove of Brazil'. ${ }^{69}$

Lemos, who attributes great causal weight to Huntington, writes, 'Two months before Huntington wrote his document ["Approaches to Political Decompression"], the government, in sync with the Harvard academic, issued Complementary Law Number 15, regulating the composition and functioning of the body that would come to elect the president of the republic. ${ }^{70}$ It is possible to interpret Lemos' statement in two ways. Either Lemos is giving Huntington credit for this law, even

\footnotetext{
${ }^{65}$ Ibid., pp. 11-12.

${ }^{66}$ Quoted in D'Araújo and Castro (eds.), Ernesto Geisel, p. 233.

${ }^{67}$ Cited in Gaspari, A ditadura derrotada, p. 344.

${ }^{68}$ It could be that Geisel and Golbery deliberately downplayed Huntington's influence so as to maximize their own autonomy and protagonism in the regime's decompression. This type of exaggeration is certainly common amongst government officials. However, comparing Huntington's advice with what the Geisel government did, it is hard to escape the conclusion that, in this instance, Geisel and Golbery are being accurate about what they thought of Huntington's recommendations at the time.

${ }^{69}$ Huntington Archive, Box 71, Folder 33 (folder marked 'Decompression Process: Notes'), note. Stanley Kubrick's 1964 film Dr Strangelove or, How I Learned to Stop Worrying and Love the Bomb had a huge cult following; Peter Sellers' portrayal of the eccentric, disturbing and slightly comical Dr Strangelove was very well known.

${ }^{70}$ Lemos, 'A conexão Harvard', p. 579.
} 
though it was passed before he wrote his paper; or what Lemos is actually recognising is that the regime leaders had dealt with the issue of presidential succession to their own satisfaction even before Huntington gave his advice to them.

Interviewed in the early 2000s by Maria D'Araújo and Celso Castro, João Paulo dos Reis Velloso, Minister of Planning in the Médici and Geisel governments, said, 'I know that there was this visit of Huntington to Minister Leitão de Abreu. At this time, there were many ideas to make Brazil a sui generis regime. The great merit of President Geisel was exactly not to have thought of anything sui generis, but only democratic opening. ${ }^{71}$

In order to demonstrate that, like the military, some members of the Brazilian academic elite did not agree with Huntington's 'Approaches to Political Decompression', we can cite the case of Wanderley Guilherme dos Santos. Described in the weekly magazine Opinião as a 'disciple of the Harvard political scientist' Huntington, Wanderley denied the connection and wrote to the magazine to refute the notion: ${ }^{72}$ he said that in the first semester of the previous year (1973) he had read a text written by Huntington on the idea of an institutional exit from the Brazilian political impasse ('Approaches to Political Decompression') in which he recommended the creation of a dominant party. Wanderley said, 'In no passage of the text is there any elaboration of what subsequently came to be known as a gradualist or incremental strategy of decompression. ${ }^{73}$ Because he disagreed with the idea of a dominant party, Wanderley wrote his own paper on the subject, 'Estratégias de descompressão politica', in 1973. ${ }^{74}$

Contrary to Lemos' claims in his 2014 article, Wanderley and Huntington were not saying the same thing, and Wanderley was correct in his letter to Opinião. His was not a Huntingtonian strategy. Just because Wanderley's approach was gradualist did not make it Huntingtonian. Any change would have been gradual under those circumstances. The regime was in charge and the armed Left had been defeated. Wanderley disagreed with Huntington because he rejected the dominantparty solution and he also prioritised the restoration of civil and political rights over the reorganisation of the system of representation. So did the regime, eventually. ${ }^{75}$

The idea of a Mexican-style solution for Brazil was common in that period. Gordon, who was close to Huntington at the time, was quoted in the Folha de São Paulo newspaper on 12 July 1972: ' $\ldots$ the democratisation of Brazil will not be like the North American [process of democratisation]. Perhaps it will be something similar to the Mexican. ${ }^{, 76}$ Juan Linz wrote about the same possibility in his essay in Alfred Stepan's Authoritarian Brazil (although Linz differed substantially from Huntington on many other issues concerning authoritarianism and

\footnotetext{
${ }^{71}$ Quoted in Maria Celina Soares D’Araújo and Celso Corrêa Pinto de Castro (eds.), Tempos modernos: João Paulo dos Reis Velloso: memórias do desenvolvimento (Rio de Janeiro: Editora FGV, 2004), p. 137. In this quote Velloso seems to be using the term 'sui generis' to mean 'generic', which is the opposite of its conventional meaning of 'unique'.

${ }^{72}$ Opinião (Rio de Janeiro), 26 Aug. 1974, p. 3; Wanderley's refutation, 2 Sept. 1974, p. 23.

${ }^{73}$ Lemos, 'A conexão Harvard', p. 585.

${ }^{74}$ Opinião (Rio de Janeiro), 2 Sept. 1974, p. 23. A copy of Wanderley's paper, which had a limited circulation, can be found in the Huntington Archive, Box 2, Folder 53, 'Political Decompression: Forecasts and Estimates'.

${ }^{75}$ Lemos, 'A conexão Harvard', p. 585.

${ }^{76}$ Quoted in Hoeveler, 'Samuel Huntington', p. 8.
} 
Brazil). ${ }^{77}$ It was common amongst modernisation theorists to think that Brazil should and could copy another Latin American model, and the Mexican model was admired by many US political scientists at that time. For a variety of reasons, the Brazilian rulers resisted this advice.

With regard to Huntington's paper 'Approaches to Political Decompression', what the regime apparently followed were very general guidelines that were almost inevitable. The transition was going to be gradual - the regime was in charge. The government was going to maintain control. Economic development was going to bring political consequences for the regime. These assertions are all focused at a fairly general level of analysis. Where Huntington was more specific - i.e. Brazil should create a dominant-party system, and it should have a sequence of reforms in which civil and political rights are restored last, after the reorganisation of the system of representation - the regime did just the opposite.

The regime restored some civil and political rights in the mid-1970s, lifting censorship, for example, and on 1 January 1979 it restored others (including habeas corpus in national security crimes) by revoking AI-5, the regime's most draconian decree. Only then did it signal a modification of the system of representation. Its sequencing was thus the reverse of what Huntington recommended.

Furthermore, the change to the system of representation was not towards a dominant-party system but instead towards a multiparty one. The government followed this policy in 1979 both to diversify representation during the regime transition and also to weaken the opposition, which otherwise would have assembled in one party. Instead of permitting only two official parties, the pro-regime Aliança Renovadora Nacional (National Renewal Alliance, ARENA) and the opposition Movimento Democrático Brasileiro (Brazilian Democratic Movement, MDB), the regime's new electoral law (Law 6767 of 1979) permitted the registration of multiple parties. This law applied to the elections of 1982, which included direct elections for governors of the states for the first time since 1965. The 1982 elections were disputed by the Partido Democrático Social (Democratic Social Party, PDS) and the Partido do MDB (Party of the MDB, PMDB) - the successors of ARENA and the MDB - and also by other parties, including two revived parties and one new party of the Left: the Partido Democrático Trabalhista (Democratic Labour Party, PDT), the Partido Trabalhista Brasileiro (Brazilian Labour Party, PTB) and the Partido dos Trabalhadores (Workers' Party, PT). Golbery had a major role in this reform, and he knew what Huntington had recommended. So Huntington's key advice about the creation of a dominant party, as well as the sequencing of reforms, was ignored.

There are several clues as to why Huntington's advice was not followed. Geisel apparently remarked that the option of a dominant-party system would have made him look even more like a dictator than he actually was. There was no tradition in Brazilian political history of dominant-party rule; instead, since 1934, elections to the lower house of the national Congress had been fought under open-list proportional representation, which created a multiparty system in that body. There

\footnotetext{
${ }^{77}$ Juan J. Linz, "The Future of an Authoritarian Situation or the Institutionalization of an Authoritarian Regime: The Case of Brazil', in Alfred Stepan (ed.), Authoritarian Brazil: Origins, Policies and Future (New Haven, CT: Yale University Press, 1973), pp. 233-54.
} 
was no plausible source of legitimacy for a dominant party, were one to have been set up. To create a dominant party, Geisel would have had to strengthen one of the two legally-permitted political parties and weaken the other. This was hardly a good way to begin a process of political 'relaxation'. Furthermore, the idea that Brazil should copy Mexico, a country outside of Brazil's natural sphere of influence, South America, was likely to invite scepticism from Brazilian officials. Mexico and Brazil shared no obvious affinities except for an occasional rivalry and mutual desire to speak for Latin America. Instead of copying the Mexican model, Golbery opted to divide the opposition in 1979 by reverting to multiparty rule.

Similarly, Geisel and Golbery did not have the luxury of adopting a rigid plan with a sequence of reforms in which representation and participation were reformed, followed afterwards by the restoration of some civil and political rights. They faced a fluid, complicated situation in which the military was riven by different factions and the opposition was divided along a spectrum of moderates at one end and more radical political forces on the other. What they needed was a strategy, a set of guiding principles about how to react in the face of opposition from the hardline forces within the regime and the critics in Congress and on the streets. What they got from Huntington was a plan. It was an erudite plan, based on in-depth empirical study of the politics of many other countries, but it was still a plan. ${ }^{78}$ The administrations of Geisel (and later Figueiredo) first restored some civil and political rights and then changed the system of representation, going against Huntington's advice to enact those reforms in the reverse order.

Furthermore, the idea that the regime could control the political transition from start to finish is questionable. Opposition parties won control of the ten largest states in 1982, including the three key states of Minas Gerais, Rio de Janeiro and São Paulo. Because state governors control the main police forces, the regime lost the capacity to repress protest in these states. The RioCentro bombing in 1981 and the deep economic recession of the early 1980s starved the Figueiredo government of popular support. The bombing was an attempt by right-wing members of the military to plant a bomb at a shopping centre in Rio the night before a First of May celebration and blame the explosion on the Left, creating a justification for further repression. The bomb exploded in the lap of one of the two military personnel at the scene, killing him (a sergeant) and seriously wounding an Army captain. ${ }^{79}$ Golbery resigned after the RioCentro bombing. Figueiredo himself refused to attend the inauguration of his successor, José Sarney, the first civilian president after the end of the military regime, alleging that the speaker of the lower house, Ulysses Guimarães, should have become president rather than Sarney: indirect election winner Tancredo Neves underwent emergency surgery hours before the

\footnotetext{
${ }^{78}$ For the distinction between plan and strategy see Lawrence Freedman, Strategy: A History (Oxford: Oxford University Press, 2013), p. xi: 'By and large, strategy comes into play where there is actual or potential conflict, when interests collide and forms of resolution are required. This is why a strategy is much more than a plan. A plan supposes a sequence of events that allows one to move with confidence from one state of affairs to another. Strategy is required when others might frustrate one's plans because they have different and possibly opposing interests and concerns.'

${ }^{79}$ See [Marsílea Gombata], 'Como deveria ser o ataque a bomba no RioCentro', Carta Capital, 20 Feb. 2014, at https://www.cartacapital.com.br/sociedade/como-era-para-ser-o-ataque-do-riocentro-506/, last accessed 12 Feb. 2021.
} 
inauguration and so Sarney, Neves' running-mate and acting vice-president, was sworn in in his place. Geisel, still powerful as an ex-president in the 1980s, criticised various aspects of the way that the Figueiredo administration handled the transition.

Fernando Henrique Cardoso, President of Brazil from 1995 to 2002, captured the inability of the regime to control the transition from start to finish when he commented on the role of civil society in the transition. He said:

[S] ociety invented agents, through the media. In the new society [emerging during the regime transition, in the 1980s], the media has a fundamental role ... Lula [Luiz Inácio Lula da Silva; founder of the PT and president 2003-10] emerged, the unions, progressive businesspeople. So, the agents were virtually created. This did not come from traditional politics, from the parties. It also did not come from the 'vision of the prince', in this case General Golbery, nor from the advice of Huntington, whom Golbery called when he planned the decompression. All of this had a role, but what gave dynamism to the process was something else: society. Another example we have is the 'Diretas Ja' ['Direct Elections Now'] campaign and yet another is the impeachment of [President] Collor [de Mello]. Society, the people, that part of the population that is organised knows how to mobilise. And what was not present begins to have weight as well. That was what was at the front of the big changes of the last few decades. ${ }^{80}$

Huntington's vision of a hegemonic political party that would encompass all of the country's major economic groups was a fantasy. Like the perfectly ordered society at West Point described at the end of The Soldier and the State, it was a world in which everyone knew his place, everyone contributed to the whole, and leaders' desires were enacted from the top down seamlessly, without tension. This was a utopian view, impossible in the Brazil of the 1970s, a country undergoing wrenching industrialisation and mass migration to cities. When the dominant-party system failed to materialise Huntington substituted it with an equally unrealistic vision of an authoritarian regime that perfectly controlled its transition to democracy, without any loss of prerogatives, any change in the social order, or indeed any perceptible difference between dictatorship and democracy.

What is puzzling is that despite the evidence, despite the glaring disparities that emerge when one compares the advice in Huntington's 1973 paper with what the regime subsequently did, scholars such as Lemos and Hoeveler insist on seeing Huntington as the mastermind of Brazil's regime decompression. A careful reading of their articles suggests that they are fundamentally interested not in the political transition from dictatorship to democracy, but in the switch from a state-guided capitalism using policies of import-substitution industrialisation to a more marketoriented economy that was more fully compatible and integrated with US capitalism. In this sense Lemos and Hoeveler are correct, in that Huntington approved of this transition too. But this should not blind them to the fact that when it came to

\footnotetext{
${ }^{80}$ Quoted in Costa Couto, História indiscreta, pp. 340-1. A similar point about the role of civil society in changing the trajectory of liberalisation is made by Napolitano, 1964, p. 233.
} 
advising the Brazilian government about how to organise a reduction in tensions within the authoritarian political regime, Huntington's practical recommendations were ignored.

For different reasons, Mendes and Huntington both saw the need for a 'decompression' of the authoritarian regime in Brazil. With regard to Huntington, he can be seen as influential only to the extent that he promoted the idea of the need for decompression. He thereby helped to legitimise the regime's decision to pursue a course of political relaxation, and he gave the regime's leaders some additional ideas to consider, as well as some international benchmarks. However, in terms of his specific recommendations, his advice was not followed.

\section{Huntington and the 'Third Wave' of Democratisation}

Huntington's subsequent intellectual trajectory can shed further light on the implications of this case study. In the early 1970s Huntington was not a scholar with a great interest in democracy. Rather, as his book Political Order in Changing Societies showed, he was primarily interested in political order, and his advice about decompression to the Brazilian dictatorial regime was based on the assumption that if done well it could stabilise the authoritarian regime. ${ }^{81}$

Huntington did not associate decompression with democratisation. He was wary of democratisation because he thought that a return to democracy in Brazil could lead to economic nationalism and/or some type of leftist populism. ${ }^{82}$ A single hand-written note found amongst his personal papers is revealing in this regard. The note reads: 'Pol. Decompression - not liberalization; not democratization. Decomp. is necessary for stability of regime - but is it???'83 In another note, Huntington wrote, 'Don't expect to elect the President [in Brazil during decompression]. ${ }^{84}$ Interestingly, Huntington's views were matched by those of his friend Mendes. In an article published in 1980, Mendes argued that because of decompression, the authoritarian regime in Brazil 'was growing in strength and is in fact preparing the way for its own institutionalization' and that 'Growing differences appear between institutionalization and democratization. ${ }^{85}$ In the terminology of the contemporary political scientist Milan Svolik, Huntington and Mendes were

\footnotetext{
${ }^{81}$ Domínguez argues that, for Huntington, political parties were key to the construction of political order: 'Samuel Huntington', p. 233.

${ }^{82}$ Huntington's views of the possible consequences of democratisation remained consistent over time. In a letter to his friend Brzezinski dated 10 March 2000 he congratulated him on the publication of his new book Living with China. He wrote, 'The only place where I might differ with you a bit concerns democratization in China. While I certainly think we should encourage movement in that direction, I also think we should not over-estimate the benefits that democracy may bring. A democratic China will not necessarily be a pro-Western China': Huntington Archive, Box 28, Folder 13.

${ }^{83}$ Huntington Archive, Box 71, Folder 33, note. Given Huntington's definition of decompression elsewhere in his personal papers, it is rather odd that he did not characterise it as a form of liberalisation in this note.

${ }^{84}$ Huntington Archive, Box 28, Folder 13, note.

${ }^{85}$ See Cândido Mendes, 'The Post-1964 Brazilian Regime: Outward Redemocratization and Inner Institutionalization', Government and Opposition, 15: 1 (Jan. 1980), pp. 48-74; here pp. 51 and 56. See also Cândido Mendes, 'The 1982 Elections in Brazil', Government and Opposition, 19: 2 (April 1984), pp. 152-6.
} 
primarily concerned with the problem of authoritarian power-sharing - how the regime could stabilise its coalition of support - rather than democratisation. ${ }^{86}$

Because of his concerns about what democracy could bring, Huntington did not recommend democratisation in Brazil in 1973 and 1974. In this respect, he was in tune with the Geisel administration. In a paper written for a US audience the year after 'Approaches to Political Decompression', he stated:

[I]f the regime should move too rapidly in the direction of decompression, the hardline reaction to this is likely to take not only an authoritarian line but also a nationalist one. In this respect, the price of maintaining an open economy may be restraint on movement toward an open polity ... Ideally, a developing country would be able to combine economic growth, socio-economic equity, an open, mixed economy, political democracy, and political stability. In fact, however, all five of these values, desirable in themselves, are seldom if ever realizable simultaneously ... Brazil, like other technocratic regimes, has opted for economic growth, an open economy, and the promise of political stability at the sacrifice of equity and democracy ... Decompression in this sense surely ought to be encouraged by the United States, so long as this does not provoke an authoritarian or nationalist reaction ... Apart from the illiberal and inhumane aspects of its authoritarian political system, the Brazilian technocratic model is congruent with American interests. ${ }^{87}$

In this passage Huntington clearly argues that the Brazilian authoritarian regime was good for the United States because it was open to investment from and trade with US partners. He believed that in an ideal world the regime would become democratic, but the risk posed by democratisation was that economic nationalists would come to power and shut out US investors and firms. Therefore, Huntington's conclusion was that the Brazilian military regime, despite its regrettable illiberal and inhumane characteristics, was compatible with US economic interests.

In the 1990s, with the rise of optimism about the spread of liberal democracy in the post-Cold War world, Huntington seems to have forgotten his scepticism about its prospects and desirability in Brazil in the mid-1970s. However, it was only in The Third Wave, published in 1991, that Huntington first made an explicit connection in his published work between decompression and democratisation. ${ }^{88}$

\footnotetext{
${ }^{86}$ Svolik, The Politics of Authoritarian Rule, p. 2. It should also be pointed out that Huntington was generally pessimistic about the prospects for more regimes to become democratic. See, for example, Samuel P. Huntington, 'Will More Countries Become Democratic?', Political Science Quarterly, 99: 2 (Summer 1984), pp. 193-218.

${ }^{87}$ Huntington Archive, Box 2, Folder 53, 'The Brazilian Political System and United States National Interests', pp. 21-2.

${ }^{88}$ The end of the Cold War sparked a re-evaluation of the importance of Latin America on the part of many US observers. For example, in a letter to Huntington dated 3 March 1992, the former Assistant Secretary of State for Inter-American Affairs Elliott Abrams, who was then a resident scholar at the Hudson Institute, wrote, 'First, the Latin and Caribbean countries are with few exceptions unimportant, developing countries ... [they] have lost the value as allies or bases that the Cold War gave them ... Historically, the American interest [in Latin America] was based on national security ... [but] the national security issue is weaker than ever before in our history ... To put it differently, Latin America will move
} 
Huntington soon returned to his previous interest in political order. His two major books after The Third Wave were The Clash of Civilizations and Who are We?, published in 1996 and 2004 respectively. In The Clash of Civilizations Huntington argued that the key feature of global politics was not the spread of democratic regimes but increasing multipolarity and tension between different 'civilisations' ${ }^{89}$ In Who are We? he questioned the compatibility of traditional elements of US national identity and liberal democracy and lamented the 'denationalization' of US business, professional, intellectual and academic elites, calling them 'dead souls'. ${ }^{90}$

The point is that even in the case of Huntington - one of the leading theorists of the 'third wave' of democratisation - and even in regard to one of the transitions that he most celebrated - the Brazilian - his support for democracy was much more recent and ambivalent than is often supposed. While it has been noted that commitment to democracy at the level of mass attitudes is weak in many thirdwave democracies, ${ }^{91}$ Huntington's personal papers and later publications show us that this commitment amongst intellectuals of the third wave, including Huntington, was also weaker than might be supposed. This insight helps us to understand the rise of authoritarian national populist movements in many democracies in the 2010s. ${ }^{92}$ It also reinforces the argument that the transitions to democracy in many new democracies such as Brazil were relatively shallow, changing formal political institutions but sometimes leaving out deeper transformations at the level of citizenship and citizen-state relations, making the regimes vulnerable to illiberal backlashes. ${ }^{93}$

from being a State/CIA/Pentagon concern to being a State/USTR [Office of the United States Trade Representative]/Commerce matter': Huntington Archive, Box 28, Folder 2, note, 'Abrams, Elliott 19922003'. Elliott Abrams became Special Representative for Venezuela in the Trump administration on 25 Jan. 2019, and was concurrently Special Representative for Iran and Venezuela from Sept. 2020 to the end of the Trump administration on 20 Jan. 2021.

${ }^{89}$ Huntington, The Clash of Civilizations, p. 46. Huntington's 'clash of civilisations' was between the Western, Latin American, Orthodox, Islamic, Buddhist, Hindu, African, Sinic and Japanese. He did not regard the Latin American civilisation as Western because of its 'corporatist, authoritarian culture' (ibid.).

${ }^{90}$ Huntington, Who are We?, p. 268.

${ }^{91}$ Roberto Stefan Foa and Yascha Mounk, 'The Signs of Deconsolidation', Journal of Democracy, 28: 1 (Jan. 2017), pp. 5-6; Paul Howe, 'Eroding Norms and Democratic Deconsolidation', Journal of Democracy, 28: 4 (Oct. 2017), p. 15; Steven Levitsky, 'Latin America's Shifting Politics: Democratic Survival and Weakness', Journal of Democracy, 29: 4 (Oct. 2018), pp. 102-3; and Yun-han Chu, Kai-Ping Huang, Marta Lagos and Robert Mattes, 'A Lost Decade for Third-Wave Democracies?', Journal of Democracy, 31: 2 (April 2020), p. 170.

${ }^{92}$ See Foa and Mounk, 'Signs of Deconsolidation'; Howe, 'Eroding Norms'; Ivan Krastev and Stephen Holmes, 'How Liberalism Became "the God that Failed" in Eastern Europe', The Guardian, 24 Oct. 2019; Levitsky, 'Latin America's Shifting Politics'; Yascha Mounk, 'The Undemocratic Dilemma', Journal of Democracy, 29: 2 (April 2018), pp. 98-112; Cas Mudde and Cristóbal Rovira Kaltwasser, Populism: A Very Short Introduction (Oxford: Oxford University Press, 2017); and Cristóbal Rovira Kaltwasser, Paul A. Taggart, Paulina Ochoa Espejo and Pierre Ostiguy (eds.), The Oxford Handbook of Populism (Oxford: Oxford University Press, 2017).

${ }^{93}$ See, for example, Robert M. Fishman, Democratic Practice: Origins of the Iberian Divide in Political Inclusion (Oxford: Oxford University Press, 2019) about the democracies in Spain and Portugal, and, for Brazilian democracy, Leonardo Avritzer, O pêndulo da democracia (São Paulo: Todavia, 2019) and Wendy Hunter and Timothy J. Power, 'Bolsonaro and Brazil's Illiberal Backlash', Journal of Democracy, 30: 1 (Jan. 2019), pp. 68-82. 


\section{Conclusion}

Huntington's engagement with the Brazilian dictatorship is well documented and an important part of the history of that regime. His commitment to conservatism, his admiration for the military way of life and values, and his scholarly work on political order in developing countries made him comfortable in advising a military regime that had come to power in a coup d'état. The fact that he was invited to Brazil by the government first in 1972, in the last year and a half of the Médici government, should alert us to the fact that liberalisation was not solely a creation of Geisel and Golbery, but instead a concern shared by many prominent actors in the previous government.

Huntington's personal papers suggest that the claim that he directly influenced the decompression implemented by the military regime in Brazil is a myth. A comparison of what he wrote in his 1973 paper 'Approaches to Decompression' and what the Geisel and Figueiredo governments did show that his recommendations were not followed. Furthermore, the comments of various well-placed individuals who were in a position to know discount the impact of Huntington. Instead, the military administrations did exactly the opposite of what Huntington told them to do - they did not reconstruct the system of representation and then restore some civil and political rights, but did things the other way around, and, when they altered the party system, they opted not for a dominant party that would aggregate society's most important interests and consolidate power in their hands, but a multiparty system that would fragment the opposition to the regime.

Furthermore, Huntington saw decompression as a way to stabilise the regime, broaden its support base, and possibly make it longer-lasting than it otherwise would have been. He feared that democratisation in Brazil in the 1970s could bring to power a government committed to economic nationalism and a reduction of opportunities for capitalist interests in the United States.

Huntington's interest in democracy was relatively short-lived. In his last book, Who are We?, he argued that elements of liberal democracy in the United States were inimical to the preservation of traditional elements of national identity in his country. In some ways Who are We? advocates for and anticipates the politics of the Trump administration (2017-21) in the United States, in that it recommends a heightened nationalism, an emphasis on a Judeo-Christian identity and the importance of 'the West', a rejection of multiculturalism and 'globalism', and policies that severely limit immigration, especially immigration from and through Mexico and from Islamic countries. In its emphasis on political order rather than liberal democracy, and its resurrection of Cold Warriors such as Elliott Abrams, the Trump administration in turn reflected the enduring preoccupations of Huntington's scholarship.

The argument in the final section of this article is that Huntington's ambivalence about democracy, and his switch from an interest in order to democracy and then back to order again (world order and the role of national identity in US political order), tell us something about the shortcomings of the 'third wave' of democratisation. If one of the leading theorists of the third wave had a commitment to democracy that was far more recent than many thought - and this theorist substantially hedged this commitment in his last two books - then the seeming 
hegemony of democratic thinking has probably been shallower than many wished to believe. This might help to explain some of the current travails of democracy, and the rise of authoritarian national populist movements in old and new democracies alike.

Acknowledgements. The author would like to thank Perry Anderson, Rogério Arantes, Rebecca Atencio, Leslie Bethell, Maria do Socorro de Sousa Braga, Ernani Carvalho, Jorge Domínguez, Christopher Dunn, Ludovico Feoli, Robert Fishman, Marcos Guedes, Frances Hagopian, Bernardo Hazen, Steven Levitsky, Felipe Loureiro, Kevin Middlebrook, Amâncio Oliveira, Janina Onuki, Leandro Piquet, Mauro Porto, Alexandre Luis Moreli Rocha, Livio Sansone and three anonymous reviewers for the Journal of Latin American Studies for comments on earlier drafts of this article. The author would also like to thank Timothy Driscoll, Senior Reference Archivist at the Harvard University Archives, for facilitating access to the Samuel P. Huntington papers: citations from these papers are courtesy of the Harvard University Archives. The author is grateful to Nancy Huntington for permission to quote from those papers. As is usual in such cases, any errors of fact and interpretation in this article are the sole responsibility of the author.

\section{Spanish abstract}

El profesor de ciencia política en Harvard Samuel P. Huntington (1927-2008) hizo dos visitas a Brasil en 1972 y 1974 para asesorar al gobierno sobre la 'descompresión' o liberalización del régimen. La literatura sobre la dictadura brasileña se refiere a estas visitas como que tuvieron un impacto causal mayor. Este artículo argumenta que su influencia en el cambio de régimen brasileño ha sido exagerada grandemente. También señala que Huntington, quien se convirtió en un teórico importante de la democratización, tuvo un interés y compromiso más reciente y circunstancial con la democracia de lo que con frecuencia se piensa. Esto ayuda a entender el actual periodo de 'desconsolidación' democrática asociada con la subida del populismo autoritario nacional en Brasil.

Spanish keywords: liberalización; Samuel P. Huntington; dictadura brasileña; democratización; democracia

\section{Portuguese abstract}

O professor de ciências políticas de Harvard Samuel P. Huntington (1927-2008) fez duas visitas ao Brasil, em 1972 e 1974, para aconselhar o governo a respeito da 'descompressão' ou liberalização do regime. A literatura sobre a ditadura no Brasil faz referência a essas visitas como tendo um grande impacto causal. Este artigo argumenta que tal influência sobre a mudança de regime no Brasil é muito exagerada. Também argumenta que Huntington, que se tornou um dos principais teóricos da democratização, tinha um interesse e um compromisso com a democracia que eram mais recentes e circunstanciais do que muitas vezes se pensa. Isso ajuda a entender o período atual de 'desconsolidação' democrática associada ao surgimento do populismo autoritário nacional no Brasil.

Portuguese keywords: liberalização; Samuel P. Huntington; ditadura brasileira; democratização; democracia

Cite this article: Pereira AW (2021). Samuel P. Huntington, Brazilian 'Decompression' and Democracy. Journal of Latin American Studies 53, 349-371. https://doi.org/10.1017/S0022216X21000250 